\title{
Portrait of Political Campaign Violations at the 2019 General Elections in Pekanbaru
}

\author{
Nabella Pusparani ${ }^{1}$, Natasya Assyura Putri², Delfy Agustina ${ }^{3}$, Defy Rizky \\ Ramadhany $^{4}$, Zullivi Muhardila ${ }^{5}$ \\ 1,2,3,4,5 Universitas Lancang Kuning \\ nabellapusparani@gmail.com
}

\begin{abstract}
This study discusses election violations in 2019, which occurred in Pekanbaru. Six reports found to Election Supervisory Agency (BAWASLU), but none of these reports was followed up by BAWASLU. This phenomenon is the basis for the researcher to conduct a study of election violations in Pekanbaru to identify the forms of violations that occur. This study uses a descriptive qualitative approach and selects the informants with purposive sampling. The data obtained from interviews with the Election Supervisory Agency Pekanbaru. The results of this study indicate that the form of violations that occur are indications of money politics committed by candidates, and there is a successful team conducting a campaign process during the quiet period.
\end{abstract}

Keywords: Campaign; Election; Money Politics

\section{Introduction}

In 2019, elections were held simultaneously throughout Indonesia, in contrast to previous elections where elections for President and Vice President and legislative elections not held simultaneously (Yandra, 2016). Many people want to occupy these seats (Mikail, 2015). Moreover, elections become an important part of representing the success of democracy that is being carried out by a country.

But on the contrary, citizens remain a high desire to become a legislative member both at the regional or central levels. Director of the Political Studies Center (Puskapol) from Universitas Indonesia (UI), Aditya Perdana, explained that many things made someone want to become a member of the board. In public, many people consider a period of pride when they become respected members of the council, are often worshipped, feel popular in the community, and are always known. The public widely discusses news about the salaries of the House of Representative (DPR) who reach hundreds of millions of rupiahs per month. There are still many people who are interested in becoming a citizen's representatives. This is because the profession is varied, even including being a spokesman for the Presidential Palace (Bramasta, 2019).

Anasrul (2019) explained that the 2019 elections participants had to campaign in useful ways to give voters a positive outlook. If the campaign delivering in a right manner, then hope to arise with a good acceptance from the community and be a pleasant election atmosphere, encouraging and motivating the public to come to the voting place (TPS) to votes their choices (Nuriyatul, 2011). But there are also areas that candidates cannot go through to campaigns such as schools and places of worship.

Furthermore, some mistakes are often found by candidates who use various methods to get them elected by the people ranging from carrying out large-scale campaigns, toppling opponents by spreading hoaxes and buying people's voices, or in other words called by dawn attack (Mardiana, 2017). Likewise, what happened in the Presidential election also done many cruel things so that they become elected leaders. Indeed, the person who did 
the heinous thing was not the person concerned to get the position, but the supporters and accomplices were the ones who did that. Maybe the word "Black Campaign" is often heard among the public, for that we need to know how many cases of campaigns that occur.

Observation of political communication assesses the black campaign as an unqualified and unintelligent way of politics. The black campaign that attacks Tribes, Religion, Race and between groups (SARA) is very uneducated and not implemented in Indonesia as a pluralist country with many tribes and religions. It is certainly dangerous if SARA becomes material for black campaigns and doing things that violate regulations in political campaigns in elections.

Some of the issues that widely used as material for political campaign violations are widely aired through social media, as well as through chain messages. The group 2 observation team conducted a study at the BAWASLU Pekanbaru Office to find out some violation findings in the 2019 Election in Pekanbaru.

Table 1

Findings of Election Violation in 2019 in Pekanbaru

\begin{tabular}{|c|c|c|c|}
\hline Reported & Stages & Follow Up & Alleged \\
\hline $\begin{array}{ll}\text { 1. } & \text { IR. Noviwaldy } \\
\text { Jusman } \\
\text { 2. } \\
\text { Hj. Arwinda } \\
\text { Gusmalinda } \\
\text { 3. } & \text { Sahril, S.H., M.H. }\end{array}$ & Campaign & $\begin{array}{l}\text { Terminated } \\
\text { /Not } \\
\text { Followed } \\
\text { Up }\end{array}$ & Criminal \\
\hline $\begin{array}{l}\text { 1. PADESI } \\
\text { 2. Dyah Ayu Nurani } \\
\text { 3. Syamsul Anwar } \\
\text { 4. Fadli Erwan } \\
\text { Ibrahim } \\
\text { 5. Fandhi Achmad }\end{array}$ & $\begin{array}{l}\text { Quiet } \\
\text { Period }\end{array}$ & $\begin{array}{c}\text { Terminated } \\
\text { /Not } \\
\text { Followed } \\
\text { Up }\end{array}$ & Criminal \\
\hline 1. Noviwaldy Jusman & $\begin{array}{l}\text { Vote } \\
\text { Count }\end{array}$ & $\begin{array}{c}\text { Terminated } \\
\text { /Not } \\
\text { Followed } \\
\text { Up } \\
\end{array}$ & Criminal \\
\hline
\end{tabular}

Source: Investigation Data from Bawaslu Pekanbaru
The Head of Bawaslu said that the way to follow up if the candidates who found to have committed an offence in a political campaign were, for example, a criminal offence, then the Bawaslu, the Police and the Prosecutor would proceed. If it is an administrative violation, then the Bawaslu follow up.

In general, what is called a black campaign is to insult, slander, pit sheep, and incite, or spread false news carried out by a candidate/group of people/political parties/supporters of a candidate, against their opponents. It is different from expressing criticism of a particular candidate's vision and mission or program that not classified as a black campaign.

\section{Theoretical Perspectives \\ 2.1Research Method}

This study uses a qualitative method with a descriptive phenomenological approach. This approach uses to understand what kind of phenomenon of violations that occur so that the root of the problem can be found and then find a solution (Fitrah, 2018). The analysis is then elaborated with an ethical and emic approach so that the findings can be balanced. Print and electronic media tracking are also used as a reinforcement of understanding about election violations in Pekanbaru.

\section{Result and Discussion}

\subsection{Dynamics of Election Violations and} Bawaslu Findings

At its essence, elections are a means available to the people to carry out their sovereignty following the principles stated in the Preamble to the 1945 Constitution. The election itself is a Democratic Institute that elects representative members the people in the MPR, DPR, DPRD, who in turn tasked with working together with the government, setting politics and running the government of the country (Kartini, 2017).

The general election is a means to realize the sovereignty of the people in the 
government of the Unitary Republic of Indonesia. Elections held to elect members of the People's Legislative Assembly, the Regional Representative Council, the Regional People's Representative Council, and elect the President and Vice President. Quality elections are elections that have the broadest possible community participation and are carried out based on direct, general, free, confidential, honest and fair principles. To elect members of representative institutions must be able to guarantee the concepts of representation, accountability and legitimacy.

In the election, there is the person in charge and the voter, the person in charge such as KPU, BAWASLU, KPPS, etc. And the voters are the people who live in the electoral environment who are 17 years old and have a KTP. In the election, there are certain participants, and election participants are political parties and individual candidates for DPRD members, political parties are electoral political parties that have fulfilled the requirements as election participants.

The campaign is an action carried out by an organization or institution that has a specific purpose and purpose by bringing the mission and vision features. The aim is to get the most votes, get support and want to be known/introduce. The campaign has been carried out since the days of the Old Order, precisely since the administration of the first President of Indonesia, Ir. Soekarno (Indrayanti, 2018).

However, for the Reformation era, more campaigns often carried out outdoors such as in the field, sports arena or sports stadium or public place, but of the many outdoor campaign agenda, not a few among the many Political Parties in our country who do indoor campaigns, like in a university building or hall.

Every political party that carries out the campaign has a strong foundation, that is, where the political party must have a large and large number of supporters. It or the party deserves to be called a significant party. So usually the time raised when the campaign be very many to thousands of people (Bastian, 2007)

The campaign carried out should be following the regulations that established so that there are no things that violate a code of ethics (Ridwan, 2018). However, human nature that sometimes addicted to money and positions makes frequent violations such as money politics and black campaigns this is certainly a fraud, which must follow up so as not to drag on.

Furthermore, for this reason, the community should also need to know that this action is not beneficial they are, this is the same as the occupation of the people's votes. If the people's votes have purchased then don't expect to have leaders who have hearts, they only prioritize money and positions, they not be fully responsible for their positions, this is what causes the many people's voices that not ignored, this should be a lesson that must be taken by the community, if there are candidates who begin to bribe or buy votes with basic food and cash the community should be able to stop it so that violations that occur in political election campaigns not entrenched in the life of a democratic society, and of course a for the welfare of the people, and for the sake of the formation of a state government leader who can serve the community well.

The dynamics of election violations through electoral campaign parties often become contentious disputes for politicians, politicians who are directly involved or parties who are not involved in the electoral party. Not only politicians, people who move outside politics are also affected by the competition of election parties before the general election takes place. Competition between political parties 
attracts public sympathy, with promises offered by political parties through the delivery of the country's development vision and mission. Political parties describe the political orientation and style so that political parties want to ask for the support of the people's votes. When the strength of the political party wins many votes, and the political party realize its vision and mission in a way that supports siding with the people (Jurdi, 2011).

Each of the methods used by political parties creates a different problem. The impact of the dynamics of these political parties results in political elites and community organizations whose institutions in community activities logically have broad access to society and society tend to be potentially exploited to attract the interests of other people to choose political parties recommended by political elites (Pramusinto \& Latief, 2011).

Every time someone gives, from all the violations reported in the Election Supervisory Agency that we get, describe as it follows:

Table 2

Findings of 2019 Election Violation in Pekanbaru

\begin{tabular}{|c|c|c|c|}
\hline Reported & Stages & Follow Up & Alleged \\
\hline 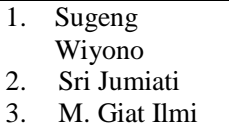 & Campaign & $\begin{array}{c}\text { Discontinued/ } \\
\text { Not Followed } \\
\text { Up }\end{array}$ & $\begin{array}{c}\text { Not } \\
\text { Infringement }\end{array}$ \\
\hline $\begin{array}{ll}\text { 1. } & \text { Teorifilaia } \\
\text { 2. } & \text { Indra Khalid } \\
& \text { Nasution, S.H. }\end{array}$ & $\begin{array}{l}\text { Quiet } \\
\text { Period }\end{array}$ & $\begin{array}{c}\text { Discontinued/ } \\
\text { Not Followed } \\
\text { Up }\end{array}$ & $\begin{array}{c}\text { Not } \\
\text { Infringement }\end{array}$ \\
\hline 1. Wan Ismail & $\begin{array}{l}\text { Vote } \\
\text { Count }\end{array}$ & $\begin{array}{c}\text { Discontinued/ } \\
\text { Not Followed } \\
\text { Up }\end{array}$ & $\begin{array}{c}\text { Not } \\
\text { Infringement }\end{array}$ \\
\hline
\end{tabular}

Source: Investigation Data from Bawaslu Pekanbaru

Election Supervisory saw from the data above that there was a report by the reporter to the Pekanbaru City Election Supervisory Agency regarding the violation of the 2019 Election Pekanbaru, but which was reported by the reporter after being investigated the results of the report are not violations.

\subsection{The tendency of Election Violations at Campaign Time}

Carried out simultaneously by-election participants according to the type of election (Election of DPR Members, Provincial DPRD, DPD City/DPRD and President and Vice President) at the campaign stage as stipulated in KPU regulations regarding the Program, and schedule of implementation election (PKPU No 5 of 2008) (Legowo, Salang \& Libertus, 2008). Election participants have the right, opportunity and fair and equal treatment in the campaign. During the campaign period, election participants have carried out several activities, ranging from face-to-face meetings to social, cultural and sporting activities that are useful to convince the public to elect candidates as future elected leaders (Pontoh, 2015).

However, Bawaslu noted that there were several reports of violations while the campaign was underway, such as in the city of Pekanbaru. The Bawaslu recorded a summary of violation report data in the 2019 general election in the form of an indication of political money by the Riau Province DPRD candidate Ir. Noviwaldi Jusman asked to be chosen as a candidate from the Democrat Party because he had sent flight tickets for 6 people from Pekanbaru-Jakarta (PP). And the ticket purchase had previously been announced by the committee on an invitation as a KIM game prize. So it is allegedly violating article 523 paragraph 1 of Law number 7 of 2017 concerning general elections.

Furthermore, a candidate from the PAN party on behalf of $\mathrm{Hj}$. Arwinda Guswamarlina, ST (reported) who nominates in electoral area Tenayan RayaSail with serial number 2. At the event, the reported party invited arisan participants to vote for them in April 17, 2019, legislative 
election and distribute campaign materials in the form of calendars and basic needs containing 1 kilo rose brand sugar and 1litre cooking oil. Then in Muara Fajar Subdistrict, Rumbai Subdistrict, the reporter on behalf of Teoriflaia was taking water behind the padesi shop alone, the RT approached the reporter and then gave examples of the DPR RI ballot papers on behalf of Kudus Kurniawan Manggapul, S.Si, MA. DPR RI candidates from the Hanura party in the Riau constituency with a total of Rp. 200,000, with a fraction of Rp.50,000,- as many as 4 sheets, Pekanbaru DPRD from the Hanura party in the electoral district of Pekanbaru City. So it is alleged to violate article 523 paragraph (2) of Law No. 7 of 2017 concerning general elections.

\subsection{Perception of Election Violations}

Violations that occur in Pekanbaru tend to be carried out by the victorious team, so the practice of violations occurred in various places in Pekanbaru due to the incomprehension of the successful team regarding campaign rules. However, not all violations reported to the Election Supervisory Agency or the KPU.

Violations that can be resolved by KPPS officers and local community institutions are not reported to institutions that deal with election problems, if KPPS and local community institutions cannot resolve the violations then they are reported to the responsible parties such as Bawaslu and KPU, even the police if the violations have occurred classified as a serious offence. Violations that occur tend to be during the campaign, but there are also violations that occur during the election and vote counting.

In scientific writing, this time we discuss election violations that often occur during campaigns such as money politics under the guise of the distribution of groceries and other items (Sarman, 2016).
Often the distribution is carried out in areas that are not too close to urban areas, more likely to villages or sub-district that are far from urban areas, and the distribution of basic needs usually done when the campaign period is over.

Many people know the purpose and purpose of the distribution of basic food items aimed at getting votes from the local community, more precisely buying the votes of the community (Kamaluddin, 2016). But they have never reported it to the competent authority even though they know it is a violation, the community uses it for their benefit, because the more candidates and their success teams come to their area, the more they get basic needs and even cash, things This is not entirely the fault of the people they take the food that given because they need the food, because the necessities of life are costly, therefore if someone gives food for free why should they refuse it? Surely they take it.

\section{Conclusion}

Based on the reports received by Bawaslu some reports indicated political money conducted by Riau Province DPRD candidates Ir. Noviwaldi Jusman asked to be chosen as a candidate from the Democrat Party because he had donated plane tickets for 6 people from Pekanbaru-Jakarta (PP). And the ticket distribution had previously been announced by the committee on the invitation as a KIM game prize. So it is allegedly violating article 523 paragraph 1 of Law number 7 of 2017 concerning general elections. Furthermore, a candidate from the PAN party on behalf of $\mathrm{Hj}$. Arwinda Guswamarlina, ST (reported) who nominates in electoral area Tenayan RayaSail with serial number 2. At the event, the reported party invited arisan participants to vote for them in April 17, 2019, legislative elections and distribute campaign materials in the form of calendars and basic needs containing 1 kilo rose brand sugar and 1 
litre cooking oil. Then in Muara Fajar Subdistrict, Rumbai Subdistrict, the reporter on behalf of Teorivilaila was taking water behind the padesi warung alone, the RT approached the reporter and then gave examples of the DPR RI ballot papers on behalf of Kudus Kurniawan Manggapul, S.Si, MA. DPR RI candidates from the Hanura party in the Riau constituency with a total of Rp. 200,000, with a fraction of Rp.50,000,- as many as 4 sheets, Pekanbaru City DPRD from the Hanura party in the electoral district of Pekanbaru City. So it is alleged to violate article 523 paragraph (2) of Law No. 7 of 2017 concerning general elections. Of all the violations reported after being analyzed based on evidence and a prolonged process, it turns out that the violations committed did not include a criminal offence, even though the reported actions were still wrong because they were fraudulent acts during the campaign.

\section{References}

Anasrul, A. (2019). Analisis Wacana Pemberitaan Pidato Tampang Boyolali Oleh Prabowo Subianto Di Media Online Mediaindonesia. com (Doctoral dissertation, UINIVERSITAS ISLAM NEGERI SULTAN SYARIF KASIM RIAU).

Bastian, I. (2007). Akuntansi untuk LSM dan partai politik. Erlangga.

Bramasta, D. Y. (2019). Selain Motif Ekonomi, Kenapa Banyak Orang Tertarik Jadi Wakil Rakyat? Kompas.com, Retrieved from https://www.kompas.com/tren/read/2 019/09/18/102104265/selain-motifekonomi-kenapa-banyak-orangtertarik-jadi-wakil-rakyat?page=all. Accessed 10 February 2020.

Fitrah, M. (2018). Metodologi penelitian: penelitian kualitatif, tindakan kelas \& studi kasus. CV Jejak (Jejak Publisher).
Indrayanti, R. D. (2018). Perbedaan Kampanye Hitam Dan Negatif Serta Hubunganya Terhadap Perilaku Pemilih Pada Pemilihan Presiden.

Jurdi, S. (2011). Muhammadiyah dalam dinamika politik Indonesia 19662006.

Kamaluddin, K. (2016). Pendidikan Politik Hubungan dengan Partisipasi Politik Masyarakat Desa Labuja Kecamatan Cenrana Kabupaten Maros (Doctoral dissertation, Universitas Islam Negeri Alauddin Makassar).

Kartini, D. S. (2017). Demokrasi dan Pengawas Pemilu. Journal of Governance, 2(2).

Legowo, T. A., Salang, S., \& Libertus, J. (2008). Panduan menjadi calon anggota DPR/DP/DPRD menghadapi pemilu. Niaga Swadaya.

Mardiana, M. (2017). Isu Sara Dalam Pilkada (Studi Kontroversi Eksploitasi Sara Dalam Black Campaign) (Doctoral dissertation, UIN Raden Intan Lampung).

Mikail, K. (2015). Pemilu Dan Partai Politik Di Indonesia: Menanti Kebangkitan Partai Politik Islam di Tahun 2019. Tamaddun: Jurnal Kebudayaan dan Sastra Islam, 15(1), 107-148.

Nuriyatul, L. (2011). Komunikasi Strategis dalam Pemilihan Umum Kepala Daerah Studi Kasus: Kampanye Pasangan Widya Kandi-M. Mustamsikin dalam Pemilihan Bupati Kendal 2010 (Doctoral dissertation, Master Program in Communication Science).

Pontoh, C. (2015). Strategi Kampanye Pemenangan Bupati Dan Wakil Bupati Terpilih Pada Pemilihan Kepala Daerah Kabupaten Minahasa. Acta Diurna Komunikasi, 4(1).

Pramusinto, A., \& Latief, M. S. (2011). Dinamika Good Governance di Tingkat Desa. JIANA (Jurnal Ilmu Administrasi Negara), 11(01). 
Ridwan, S. (2018). Pelanggaran Kode etik Ketua KPU Kab. Dharmasraya dalam pemilukada Serentak Tahun 2015 (Doctoral dissertation, Universitas andalas).

Sarman, M. (2016). Peran Tuan Guru dalam Peta Politik Lokal.

Yandra, A. (2016). E-goverment dengan Memanfaatkan Teknologi

Informasi. POLITIK, 12(1), 1769. 